\title{
Contextual factors promoting psychosocial well-being and safe sexual behaviour in African male youth: A literature review
}

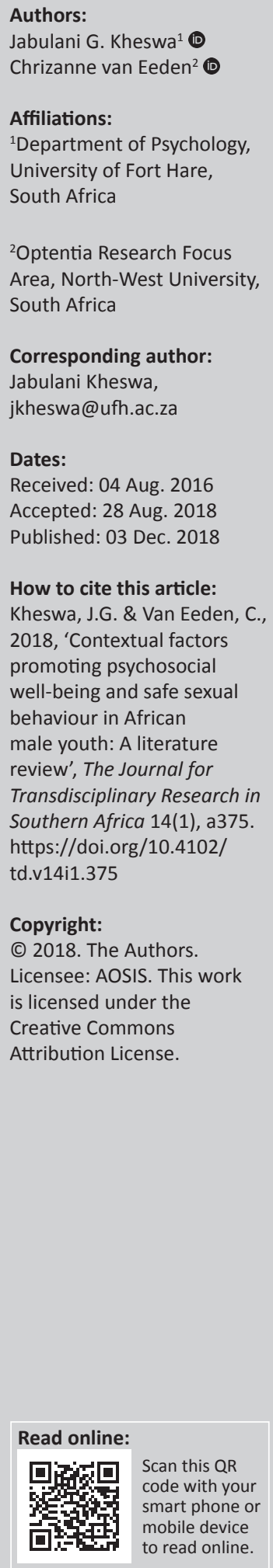

Authors:

Affiliations:

South Africa

Area, North-West University,

Corresponding author:

Jabulani Kheswa,

Dates:

Received: 04 Aug. 2016

Accepted: 28 Aug. 2018

How to cite this article: Kheswa, J.G. \& Van Eeden, C co18, 'Contextual factors well-being and safe sexual behaviour in African male youth: A literature review', The Journal for Transdisciplinary Research in https://doi.org/10.4102/

td.v14i1.375

Copyright:

(c) 2018. The Authors. Licensee: AOSIS. This work is licensed under the Creative Commons Attribution License. mobile device
to read online.

\begin{abstract}
This article reviewed literature on the psychosocial well-being of adolescent males and found that there is still a dearth of research addressing their mental health and well-being in relation to sexuality. The aim of this article was to highlight the contextual factors which may play an important role in promoting safe sexual behaviour of adolescent males, especially in South Africa, where sexually transmitted infections, teenage fatherhood and substance abuse continue to reach alarming proportions. For data collection, a desktop review was employed for its usefulness in identifying and addressing the gaps from previous studies. Grounded in theories of human development and psychological well-being, this article concludes that provision of emotional support and healthy parent-child relationships, quality peers, constructive environment and adequate knowledge from traditional male circumcision mentors may contribute to adolescent males' safe sexual practices, decisionmaking skills and mental health.
\end{abstract}

\section{Introduction}

During adolescence, young males become more independent of parents, start to explore life's possibilities (Zastrow \& Kirst-Ashman 2007) and vary greatly from one culture to another, and are influenced by social, economic, political and cultural factors (Carroll 2016). Erikson's theory of psychosocial development through stages describes adolescence as a developmental transition between childhood and adulthood. There are four psychosocial stages before an adolescent begins to establish a stable identity, namely basic trust versus mistrust (from infancy to 12 months old), autonomy versus shame and doubt (from 1 to 2 years old), initiative versus guilt (from 3 to 6 years old) and industry versus inferiority (from 7 to 11 years old) (Louw \& Louw 2014). During this fifth developmental stage (identity vs. confusion), adolescent males learn how to answer the question of 'who am I' and search for a true self (Schultz \& Schultz 2013; Swartz et al. 2016), or an identity that will lead them to adulthood, because they now have to make deliberate decisions and choices, especially about vocation, sexual orientation and life in general (Schultz \& Schultz 2013). Drawing from implicit theories of relationships developed by Dweck (1996), when adolescent males believe in the destiny (i.e. compatibility) of the relationship, they may feel more satisfied and emotionally secure in prolonging their romantic relationships, whereas those who feel emptiness although they are in a relationship may end it quickly.

However, through modelling when adults or parents engage in substance abuse and violence, it is most likely that adolescents would learn inappropriate behaviour such as bullying and sexually coercing girls as a sign of expressing their masculinity (Pastorino \& Doyle-Portillo 2011; Peterson, Janssen \& Heiman 2010). For example, in a study conducted in Cape Town among Grades 8-11 learners, Holborn and Eddy (2011) found that 21\% of adolescent males who grew up seeing verbal and physical fights between parents reported to use violence against their partners. Not surprisingly, adolescent females in Soweto, Gauteng province, mentioned intimate partner violence and sexual abuse (Makongoza \& Nduna 2017). In Braamfischerville, Soweto, seven adolescent males between 13 and 19 years of age gang raped a 17 year- old mentally challenged girl and the act was captured on their cellphones (Holtzhausen 2012). The question that should be asked is the following 'to what extent is the adolescent males' sexual behaviour safe and how knowledgeable are they about the repercussions of gang rape'? In a study on condom use in the Eastern Cape province among adolescent males among the traditional Xhosa culture, Nyembezi

Note: This article is partially based on the author's thesis of the degree PhD in the School of Behavioural Sciences (Psychology) in the Faculty of Humanities at the North-West University (Vaal Triangle Campus), South Africa, with promoter Prof. C. van Eeden and copromoter Prof. S. Rothmann, received May 2016, available here: http://dspace.nwu.ac.za/bitstream/handle/10394/20489/Kheswa_ JG.pdf?isAllowed=y\&sequence $=1$. 
et al. (2014) found that about $49 \%$ did not use condoms. Astonishingly, in KwaZulu Natal province, adolescent males who underwent voluntary medical male circumcision (VMMC) reported resumption of anal and vaginal intercourse during the healing period with multiple sexual partners and without using condoms (George et al. 2017).

\section{Problem statement}

The majority of the research conducted on adolescent females' sexual behaviour focused on teenage pregnancy, transactional sex (Zembe et al. 2015; Zuma et al. 2016), abortion and intimate partner violence, depressive episodes resulting from maltreatment and drugs and alcohol abuse (Kheswa 2017a). Among adolescent males, the shift has always been on investigating their sexual aggressive behaviour, hegemonic masculinity (Ratele, Shefer \& Clowes 2012), traditional male circumcision (Nkosi et al. 2015), delinquency, recidivism and effects of child sexual abuse, being reared in foster care or in dysfunctional families without providing strategies to improve their psychosocial well-being (Langa 2016). For example, Shai et al. (2012) found adolescent males in the Eastern Cape, who have been under the guidance of unscrupulous traditional nurses 'amakhankatha' during traditional male circumcision period, developed antisocial behaviour and sexually violated girls and belonged to gangsters. African adolescent males have undergone traditional circumcision even if at age 16, they are regarded as men and it is deemed acceptable for them to drink alcohol and have multiple sexual partners (Jewkes \& Morrell 2017; Ntombana 2011). Thus, this article intends to elucidate the contextual factors relating to the promotion of psychosocial well-being among African male youth. In comparison, no research has been conducted to investigate mental health and well-being in relation to sexuality aspects of youth.

\section{Research objectives}

Based on the past literature, the research objectives of this study are as follows:

- to determine the factors leading adolescent males to engage in (un)safe sexual behaviour.

- to discuss how best the psychosocial well-being of adolescent males may be improved.

\section{Research methodology}

This article employed the systematic review as a relevant research methodology based on several advantages. Systematic reviews entail a search strategy and detailed plan, aimed at reducing bias by identifying, evaluating and synthesising all relevant studies on a specific topic (Uman 2011). Relative to an empirical study which commends direct involvement of the researchers, the desktop review examines literature studies from academic journals, books and Internet sources to get an overview and clarify the need for safe sexual practices among African adolescent males. The researchers employed a desktop review to search for published peerreviewed studies that explored the factors leading to risky sexual behaviour of adolescent males living in South Africa. Electronic searches of articles that were assessed for this study are indexed PsycINFO, EMBASE, Scopus and International Bibliography of the Social Sciences (IBSS). Because this research method has no restrictions, however, the articles had to meet the following inclusion criteria: (1) adolescent males whose age does not exceed 18 years, (2) affected by poverty, orphanhood, disorganised environment, culture, sexual abuse, violence, alcohol and drug abuse, and human immunodeficiency virus (HIV). In this regard, the researchers' arguments may be important following a thorough explanation of the evaluation of the past literature.

\section{Theoretical framework}

This article adopted a multi-theoretical approach owing to the nature of the challenges faced by adolescent males and the intended goals. Bowlby's (1969) attachment theory, Erik Erikson's psychosocial developmental stages (Swartz et al. 2016), the broaden-and-build theory of Fredrickson (2002), Bronfenbrenner's (1979) ecological model, Keyes's (2009) mental health, Diana Baumrind's topology of parenting styles (Louw \& Louw 2014) and Lazarus and Folkman's (1990) theory on coping and stress underpinned this literature article.

\section{Literature review}

Psychosocial well-being is the preferred concept for this study of male youth in a collective African culture. It implies an extension of psychological well-being to include interpersonal and sociocultural functioning in the concept of optimal mental and physical wellness. In this regard, Weiten (2010) stated that psychosocial well-being in adolescence refers to identity formation and self-awareness with regard to sexual, moral and psychological development within a specific sociocultural context. A wellness enabling sociocultural context would feature, among other factors, discussed next.

\section{Home or family life}

According to Compton and Hoffman (2013), a healthy home or family is an institution that is characterised by commitment to the psychological, emotional and social well-being of its members through encouragement of individual autonomy and responsibility. Gur (2011) found that when there are respectful patterns of communication among all family members, religious orientation and clear household rules and boundaries between adolescents and parents, an authoritative rather than authoritarian or permissive parenting style may produce adolescents who are resilient and flexible against adverse events. For adolescent males in particular, Compton (2005) found that households with good structure and discipline, a male role model and encouragement of emotional responsiveness contribute to their resilience. In contrast, when parents are involved in criminal acts or abusive behaviours, have disordered family communication patterns, are poor, and live in stressful and 
drug-friendly environments, the psychosocial well-being of adolescent males may be distorted (Coon \& Mitterer 2010). For example, $68.9 \%$ low-income adolescents in peri-urban areas in Johannesburg reported smoking marijuana, whereas 53\% indicated to have used alcohol (Magidson et al. 2017). Kheswa (2017b) outlined in his phenomenological study on unemployed youth in the Eastern Cape that exclusion of adolescent males from the economy despite good grades attained from matric results in many securing respect through drug-dealing, use of violence against women because of boredom and frustration. From a psychoanalytic viewpoint, Sigmund Freud's theory posits that such males might have been neglected during oral, anal and phallic stages, when the caregivers should have provided warmth, shelter, food, toilet training and identify gender roles (Swartz et al. 2016).

\section{Attachment}

The term 'attachment' refers to the strong emotional bond that develops between children and their primary caregivers (i.e. parents) (Pastorino \& Doyle-Portillo 2011) and once formed early in life and maintained throughout childhood, it may contribute to life satisfaction in adulthood (Armstrong, England \& Forgaty 2012; Bowlby 1969). Secure attachment is characterised by unconditional support and love that is invested by parents in their relationships with their sons (Bernstein 2016) and such relationships may facilitate leadership qualities and positive well-being in youth (Louw \& Louw 2014), as reflected by characteristics of self-esteem, emotional adjustment and physical health (Kheswa 2015). Kheswa (2015) emphasised that healthy bonding with caregivers may actualise adolescent males in the following psychosocial well-beingrelated strengths, namely social, emotional, cognitive, behavioural and moral competence, self-efficacy, selfdetermination and positive identity formation, spirituality, beliefs in the future, prosocial norms and involvement. Drawing from the most widely used typology of attachment secure, avoidant and ambivalent attachment developed by Mary Ainsworth (Engler 2009; Louw \& Louw 2014), Koen (2009) found that secure attachment was significantly related to positive parent-adolescent communication and to family satisfaction as experienced by adolescents.

In Koen's study mentioned above, attachment anger or emotional detachment from parents was the strongest predictor of emotional distress in youth in South Africa (Koen 2009). Also, in a 2012 study on psychosocial well-being of families in South Africa, Koen found that from a large group of adolescents $(n=772)$ only $36 \%$ reported experiencing their families as psychosocially well. An alarming percentage $(64 \%)$ indicated that they were not experiencing optimal psychosocial wellness in their families. These findings were in line with an in-depth study carried out by Holborn and Eddy (2011) about the extent of family breakdown in South Africa. In other words, it could be concluded that avoidant and ambivalent attachment experienced by adolescents contributed towards emotional and social insecurity relational incompetence because of lack of parental support (Carr 2011; Schultz \& Schultz 2009).

\section{Adolescent-parent relationship}

Substantial research documented that a sound adolescentparent relationship not only promotes prosocial behaviour but also harnesses clear sexual values and attitudes among youth in South Africa (Kheswa \& Lobi 2017; Melato et al. 2017). However, factors such as divorce and the resulting single parenthood and fatherless homes, orphanhood, homelessness, child-headed households and child abuse have the propensity to negatively impact their sexual behaviour owing to lack of emotional support and open communication about sexuality (Hensels et al. 2016). Roman, Makwakwa and Lacante (2016) found that inconsistent parenting-child behaviour outcomes in South Africa lead to improper and inadequate discipline of boys; hence they often have multiple sexual partners. Alternatively, adolescent males who have experienced sexual abuse or coercion from their male relatives and adults are prone to risk sexual behaviour (Naidoo \& Sewpaul 2014) as Abousselam et al. (2016) found that in Mangaung, FreeState province, the majority of study participants engaged in unprotected anal and vaginal intercourse. Given that in child-headed households, unemployed and fatherless homes, adolescent males may struggle to survive economically (Holborn \& Eddy 2011), there is a likelihood of resorting to male prostitution with older men in exchange for money (Masvawure et al. 2016). In such instances, they may develop human papillomavirus (HPV) and anal cancer since unprotected receptive anal intercourse is 16 times more likely to transmit HIV as compared to unprotected vaginal intercourse (Baggaley, White \& Boily 2010). As compared to developed countries which provide evidence-based programmes to its youth for responsible sexual behaviour, programmes such as Stepping Stones are not sufficient in South Africa to reach to adolescent males especially in rural areas. The underlying reason for such concern is because HPV is asymptomatic and in Cape Town, $44 \%$ of young men who have sex with men (MSM) were reported to be HIV positive while $91.8 \%$ had anal HPV infection (Müller et al. 2016).

\section{Education and healthy schools}

According to the National School Climate Council (2007), a healthy school should embody learners with the zeal to acquire knowledge, skills and values from the educators and school personnel are responsible for ensuring that a conducive climate prevails for teaching and learning and responsible parents for financial, emotional and psychological support. Basson (2008) is of the opinion that educators should act as role models, sources of support and provide positive feedback to unleash the potential of every learner, whereas the South African Council for Educators (SACE) Code of Conduct (Macnab 2013) calls for educators to exercise authority with compassion, avoid physical and psychological abuse and refrain from any form of sexual harassment of learners. However, Suldo et al. (2012) suggested that schools that are characterised by violence could be a place of misery and shame for adolescent males who may be bullied and victimised by delinquent peers to engage in risk activities 
such as experimentation with sex, alcohol and drugs. For fear of being ridiculed, such youth may develop defence mechanisms such as suppression, by not reporting the atrocities done to them to their educators and parents, resulting in their academic performance deteriorating because of preoccupation with their experienced anxiety, being unable to concentrate and actively participate during lessons. Furthermore, the outcomes of stressful experiences by such youth may include externalising behaviours such as aggression, disturbance in sleep patterns, conflicts and breakup of romantic relationships because of their inability to cope (Bach \& Louw 2010; Donald, Lazarus \& Lolwana 2010; Mume, Olawale \& Osundina 2011).

\section{Constructive peer relationships}

Drawing from group socialisation theory, which proposes that the most influential environmental factor in shaping the personality of an adolescent is the peer group (Espelage 2014), the need to belong to and make friends with significant others outside the family is inevitable (Carroll 2016). Intimacy with and commitment to friends appear in early adolescence and may provide protection against risk behaviour such as alcohol consumption and smoking of tobacco, skipping of classes and rebelliousness (Carlo et al. 2010). Healthy peer groups could be determining factors with regard to an adolescent's happiness and emotional well-being (Johnston \& Krettenauer 2011). By spending quality time with such peers, adolescents' positive thinking and setting of realistic future goals could result in the enhancement of their social world and be linked with emotional and psychological wellbeing (Kocayörük 2010).

Irrespective of insecure attachment to parents as a result of divorce, poverty or inability to provide consistent support to the adolescent, Bester (2009) found that by maintaining constructive peer relationships, adolescent males' selfimage can be strong. Drawing from Fredrickson's (2003) broaden-and-build theory of positive emotions, Zeman, Cassano and Adrian (2012) proposed that peers could be perceived as a reliable resource for adolescents' emotional well-being in the following manner: intellectually, youth may flourish by studying in groups and develop reasoning and problem-solving skills, psychologically, they could become resilient in spite of adversity, be optimistic about the future and learn to cope in their environment, and socially, they could be provided with support to acquire physical skills.

\section{Community safety and environmental support}

It is important to note that adolescents' development is also connected to their social and cultural environments, especially their communities because those transmit values and attitudes necessary for healthy living (Liebenberg, Ungar \& Van de Vijver 2012). According to Crone and Dahl (2012), the social environment in which adolescents develop plays a critical role in shaping their behaviour, attitude and sense of the self. For optimal functioning of youth, structures within the community (e.g. non-governmental organisations [NGOs] and churches) should take initiatives in implementing programmes to alleviate risk factors such as instability caused by violence, crime, HIV/AIDS and teenage pregnancy (Moshabela et al. 2016). Ungar (2011) has extensively found that a supportive and enabling sociocultural ecology is a powerful determinant in the ability of youth to rebound from adversity and trauma.

However, in informal settlements which are often enmeshed in violence and drug abuse owing to less social cohesion (Mcllwaine 2012), adolescent males may find it hard to escape early sexual encounters in the midst of peers who are sexually active and aggressive. To appear as real men among their peers and to avoid to be labelled as gay, Miller et al. 2016) found that such youth often succumb to coercive sex initiated by peers or girlfriends. According to Brown, Testa and Messman-Moore (2009) coercive sex may entail incapacitation through alcohol and drug abuse and result in unintended teenage fatherhood and high probability of STI. Alcohol myopia theory asserts that alcohol consumption alters one's reasoning and ability skill to make informed decisions; hence a disproportionate number of male youth continue to get infected by HIV owing to non-condom use during sex (Walsh et al. 2017). Excessive alcohol consumption has been shown to be associated with harmful notions of masculinity which encourage unsafe sexual behaviour among males (Rich, Nkosi \& Morojele 2015). In a study that Rich et al. (2015) conducted in the North-West province, it became clear that in culturally embedded societies, men grow up with the mentality that females who attend taverns or social clubs wearing short skirts and drinking alcohol need sexual partners, thus they end up raping them. Thus, this research article advocates the need for sex education for male youth and self-confidence for those who intend to delay sexual activities until they are emotionally, financially and psychologically ready.

\section{Mental health and well-being}

According to Keyes (2009) a state of complete mental health and well-being is one in which there is emotional, psychological and social well-being present.

\section{Emotional well-being}

The impact of positive emotionality can be substantial, ranging from higher well-being to better romantic relationships, improved memory and attention, exhibition of altruism and generosity, more successful careers, the promotion of creativity and better health (Lyubomirsky, King \& Diener 2005). Fredrickson (2009) found that strong emotional well-being is associated with openness to new experiences, greater cognitive flexibility, and a deeper sense of meaning. Such individuals are comfortable in conveying love, kindness and spending time empowering others with positive experiences. The experience of positive emotions is the fundamental feature of the broaden-and-build theory of Fredrickson (2002), which posits the ability of positive 
emotional experiences to broaden one's immediate thoughtaction repertoires. Such broadening of thought-and-action builds enduring personal resources and leads to personal growth and resilience through adaptive spirals of emotion, cognition and action (Carr 2011; Fredrickson 2009). A large body of evidence shows the positive effect of positive emotional experiences on the well-being of youth and salutary outcomes when used in positive youth development (Davidson \& McEwen 2012; Garcia 2011).

\section{Social well-being}

The five dimensions of social well-being are social acceptance, social actualisation, social contribution, social coherence and social integration (Keyes 1998). Social acceptance refers to the degree to which individuals hold positive attitudes towards others and how they relate to one another. Social actualisation refers to the extent to which individuals believe that their society can become a better place, while social contribution refers to how people believe that their involvement makes a valuable impact on their communities (Zhang et al. 2011). Adolescent males who show social-bonding tend to share their vision and goals and empower others, while taking charge of their lives and thereby enhancing their efficacy (Christens \& Peterson 2012). Such individuals implement meaningful changes in their environment and assist where possible to reduce antisocial acts such as crimes that involve homophobic attacks. Thus, researchers such as Ratele (2014) advocate socio-psychological transformation because Breen et al. (2016), Morrissey (2013) and Müller (2016) found that in many parts of South Africa, excluding white communities, sexual violence and discrimination towards lesbian, gay, bisexual, transgender and intersex (LGBTI) was rampant.

This means that through empowerment, a sense of collective efficacy is experienced and there is cooperation among all community members (Compton \& Hoffman 2013). Adolescent males who exhibit social wellness may ensure that their surroundings (neighbourhood, school and parks) are secured and safe (Coon \& Mitterer 2010).

\section{Self-esteem}

According to Neff (2011), self-esteem is related to optimism in the cultural context and is composed of four features: (1) feeling that one is accepted by significant others, (2) being the recipient of positive evaluations from others, (3) believing that one compares favourably to other people or to one's ideal self and (4) believing that one can initiate effective action in one's world. Studies have found that self-esteem is associated with less delinquency, better anger control, more emotional intimacy and satisfaction in relationships, more ability to care for others and a heightened capacity for creative and productive work (Collins, Haydon \& Hesemeyer 2007; Neff 2011). For example, a South African study about sport participation and psychosocial well-being by Malebo, Van Eeden and Wissing (2007) found that sport participation was significantly related to higher levels of positive affect, sense of coherence and self-efficacy beliefs and to lower levels of negative affect, somatic symptoms and pessimistic life orientation, as experienced by a group of African students. However, men with history of sexual abuse in Duncan Village, Eastern Cape, expressed low self-esteem, risky sexual behaviour with multiple sexual partners and less affection towards their partners (Icard et al. 2014). It therefore means that adolescent males should be protected from an early age from all forms of neglect and maltreatment.

\section{Coping strategies}

The term 'coping' was conceptualised by Lazarus and Folkman (1990) as the process to describe how individuals use their cognitive and behavioural efforts to manage emotional and environmental stressors, and adaptive coping involves confronting challenges directly and reasonably in a taskoriented way. Weiten (2010: 547) defines coping as the active efforts to master, reduce, or tolerate the demands created by stress' and posits that coping is clustered into two broad categories, namely problem-solving and emotive-focused coping. Problem-solving efforts involve active involvement in alleviating stressful circumstances by seeking and utilising advice, assistance and relevant information from peers, educators or parents (Yendork \& Somhlaba 2014). Problemfocused coping enables adolescents to increase their selfesteem and self-regulation to buffer them against risky behaviours and to respond to traumatic life events (e.g. divorce, death of parents, child abuse and academic failure) with what Martin Seligman called 'learned-optimism' (Compton 2005).

Emotion-focused coping involves regulation of one's thoughts and actions to relieve the emotional impact of stress (Carlo et al. 2012). Emotion-focused coping as an adaptive process to counteract stress is reported to equip individuals with the self-control of emotions in the midst of challenges by enabling such individuals to comply, manage and remain focused (Skinner et al. 2008). For example, as compared with adolescent males who employ avoidance strategies in dealing with their problems, Ojala (2013) found that the emotionally focused youth do not sit back and do nothing; instead they become optimistic and resilient in their coping actions.

However, Garcia (2011) argued that adolescents are confronted by a wide range of stress-related risks such as depression, suicidal ideation, sexual abuse, HIV/AIDS infection, domestic violence and sibling rivalry as they interact with their peers, educators and family members. Drawing from Bronfenbrenner's (1979) ecological model, adolescent males who are raised in family settings characterised by hardships such as unemployment, divorce and substance abuse may lack coping self-efficacy to complete their schooling relative to adolescents whose parents afford to meet their educational needs (Coyle et al. 2009). For example, in a study conducted by Pretorius (2009) on support systems and coping strategies used by South African children of divorced parents in Cape Town, $46 \%$ of adolescent males indicated that divorce of their parents created in them resentment, social maladjustment and attention deficits as their academic performance deteriorated. 
Religious coping may increase hope, positive emotions, compassion, generativity and optimism, promote personality integration and support healthy lifestyles (e.g. encouraging monogamous relationships and prohibiting alcohol consumption) (Berg et al. 2009). In a South African study on adolescents' perceptions of religion in Soweto, Brittian, Lewis and Norris (2013) reported that $70 \%$ of the participants who were rooted in some form of religion engaged in socially approved behaviour and prolonged engagement in sexual activities because their religion provided them with support, moral compass, promoted healthy development and intersections between African traditional practices and Christian beliefs.

Hardiness is a concept used to describe how well mentally and physically an individual reacts to a stressful situation (e.g. traumatic events and sexual exploitation) (NolenHoeksema 2008). It is defined as the combination of three cognitive factors involved with how individuals interpret their life experiences, namely a sense of control, greater cognitive flexibility and a sense of commitment (Van Dyke et al. 2009). Adolescent males with hardiness are more inclined to take charge of their immediate surroundings and feel confident that they would cope and deactivate the stressful situation (Levine et al. 2009). Such youth do not procrastinate and in coping with the situation, they draw strength from their environment. This approach is what Antonovsky (1987) referred to as general resistance resources (GRR), a feature of a life orientation based on a sense of coherence or the beliefs that life is understandable, manageable and meaningful. Because there is an inextricable link between hardiness and emotional intelligence, Salovey and Mayer (1990), who pioneered the original model of emotional intelligence, proposed that any adolescent male who is emotionally intelligent tends to accurately recognise what they are feeling when they are feeling it, handle interpersonal relationships, use emotions to motivate themselves (e.g. to guide their emotions to remain focused and attain their goals). Finally, they tend to recognise emotions in others, and regulate their moods, handle stress and rebound after experiencing an emotional setback.

\section{Conclusion}

It is thus concluded that although recognition is given in the literature to mostly objective indicators of sexual behaviour of African male youth such as the ages of sexual debut, certain - mostly negative - health practices such as risky sexual activities, lack of condom use, multiple partners and aggressive actions in sexual encounters, more subjective dimensions of sexuality development in youth have received little attention. Also the study of well-being may seem less pressing than the obviously urgent problem-saturated developmental aspects of adolescents, such as violence, sexual risk behaviour and substance abuse. However, the lack of research into psycho-sexual health and well-being of youth limits our understanding of positive sexuality of adolescents and how their well-being in this regard could be facilitated and enhanced.

\section{Acknowledgements Competing interests}

The authors declare that they have no financial or personal relationships that may have inappropriately influenced them in writing this article.

\section{Authors' contributions}

J.G.K. performed most of the conceptual contributions and was the project leader as this manuscript is from his $\mathrm{PhD}$ thesis. C.v.E. was responsible for technical and language editing. Furthermore, being a promoter, she guided the project leader in terms of academic writing.

\section{References}

Abousselam, N., Naudé, L., Lens, W. \& Esterhuyse, K., 2016, 'The relationship between future time perspective, self-efficacy and risky sexual behaviour in the Black youth of central South Africa', Journal of Mental Health 25(2), 176-183. https://doi.org/ 10.3109/09638237.2015.1078884

Antonovsky, A., 1987, Unraveling the mystery of health: How people manage stress and stay well?, Josser-Bass Publications, San Francisco, CA.

Armstrong, E.A., England, P. \& Fogarty, A.C.K., 2012, 'Accounting for women's orgasm and sexual enjoyment in college hookups and relationships', American Sociological Review 77, 435-462. https://doi.org/10.1177/0003122412445802.

Bach, J.M. \& Louw, D., 2010, 'Depression and exposure to violence among Venda and Northern Sotho adolescents in South Africa', Africa Journal of Psychiatry 13, 25-35.

Baggaley, R.F., White, R.G. \& Boily, M.C., 2010, 'HIV transmission risk through anal intercourse: Systematic review, meta-analysis and implications for HIV prevention', International-Journal of Epidemiology 39(4), 1048-1063. https://doi. org/10.1093/ije/dyq057

Basson, N., 2008, 'The influence of psychosocial factors on the subjective well-being of adolescents', Doctoral dissertation, University of the Free State, Bloemfontein.

Berg, C., Choi, W.S., Kaur, H., Nollen, N. \& Ahluwalia, J.S., 2009, 'The roles of parenting, church attendance, and depression in adolescent smoking', Journal of Community Health 34(1), 56-63. https://doi.org/10.1007/s10900-008-9118-4

Bowlby, J 1969, Attachment and loss; Attachment, Basic Books, New York.

Breen, D., Lynch, I., Nel, J. \& Matthews, I., 2016, 'Hate crime in transitional societies: The case of South Africa', in J. Schweppe \& M.A. Walters (eds.), The globalization of hate: Internationalizing hate Crime?, pp. 126-141, Oxford University Press, Cape Town.

Brittian, A.S., Lewin, N. \& Norris, S.A., 2013, 'You must know where you come from: South African youths' perceptions of religion in time of social change', Journal of Adolescent Research 28(6), 642-663. https://doi.org/10.1093/acprof:oso/ of Adolescent Research 2816
9780198785668.003 .0009

Bronfenbrenner, U., 1979, The ecology of human development: Experiments by nature and design, Harvard University Press, Cambridge, MA

Brown, A.L., Testa, M. \& Messman-Moore, T.L., 2009, 'Psychological consequences of sexual victimization resulting from force, incapacitation, orverbal coercion', Violence Against Women 15, 898-919. https://doi.org/10.1177/1077801209335491

Carlo, G., Mestre, M.V., McGinley, M.M., Samper, P., Tur, A. \& Sandman, D., 2012, 'The interplay of emotional instability, empathy, and coping on prosocial and aggressive behaviours', Personality and Individual Differences 53(5), 675-680. https://doi.org/10.1016/j.paid.2012.05.022

Carr, A., 2011, Positive psychology: The science of happiness and human strengths, Bruner-Routledge, New York, NY.

Carroll, J.L., 2016, Sexuality now. Embracing diversity, 5th edn., Cengage Learning, Boston, MA.

Christens, B.D. \& Peterson, N.A., 2012, 'The role of empowerment in youth development: A study of sociopolitical control as mediator of ecological systems' influence on developmental outcomes', Journal of Youth and Adolescence 41(5), 623-635. https://doi.org/10.1007/s10964-011-9724-9

Collins, W., Haydon, K.C. \& Hesemeyer, P., 2007, 'Relating relationships: Development, expansion, and interrelations in relationship networks' International Journal of Behavioural Development 31(6), 581-584. https:// doi.org/10.1177/0165025407080587

Compton, W.C., 2005, Introduction to positive psychology, Thomson Wadsworth, Belmont, CA.

Compton, W.C. \& Hoffman, E., 2013, Positive psychology: The science of happiness and flourishing, 2nd edn. Wadsworth Cengage Learning, Belmont, CA.

Coon, D. \& Mitterer, J.O., 2010, Introduction to psychology: Gateways to mind and behaviour. Study guide, Wadsworth Cengage Learning, Belmont, CA.

Coyle, J.P., Nochajski, T., Maguin, E., Safyer, A., DeWit, D. \& Macdonald, S., 2009, 'An exploratory study of the nature of family resilience in families affected by parental alcohol abuse', Journal of Family Issues 30(12), 1606-1623. https://doi. org/10.1177/0192513X09339478 
Crone, E.A. \& Dahl, R.E., 2012,'Understanding adolescence as a period of socialaffective engagement and goal flexibility', Nature Reviews Neuroscience 13(9), 636-650. https://doi.org/10.1038/nrn3313

Davidson, R.J. \& McEwen, B.S., 2012, 'Social influences on neuroplasticity: tress and interventions to promote well-being', Nature Neuroscience 15(5), 689-695. https://doi.org/10.1038/nn.3093

Donald, D.R., Lazarus, S. \& Lolwana, P., 2010, Educational psychology in social context: Ecosystemic applications in southern Africa, 4th edn., Oxford University Press, Cape Town

Dweck, C.S., 1996, 'Implicit theories as organizers of goals and behaviour', in P. Gollwitzer \& J.A. Bargh (eds.), The psychology of action: Linking cognition and motivation to behavior, pp. 69-90, Guilford, New York.

Engler, B., 2009, Personality theories, 8th edn., Wadsworth Cengage Learning, Australia.

Espelage, D.L., 2014, 'Ecological theory: Preventing youth bullying, aggression, and victimization', Theory into Practice 53(4), 257-264. https://doi.org/10.1080/004 05841.2014.947216

Fredrickson, B., 2009, Positivity: Top-notch research reveals the 3 to 1 ratio that will change your life, Random House LLC, New York, NY.

Fredrickson, B.L., 2002, 'Positive emotions', in C.R. Snyder \& S.J. Lopez (eds.), Handbook of positive psychology, pp. 120-134, Oxford University Press, New York.

Fredrickson, B.L., 2003, 'The value of positive emotions', American Scientist 91(4), 330-335. https://doi.org/10.1511/2003.4.330

Garcia, D., 2011, 'Two models of personality and well-being among adolescents', Personality and Individual Differences 50(8), 1208-1212. https://doi.org/10.1511/ 2003.4.330

George, G., Govender, K., Beckett, S., Montague, C. \& Frohlich, J., 2016,'Early resumption of sex following voluntary medical male circumcision amongst schoolgoing males', PLoS One 11(12), e0168091. https://doi.org/10.1371/journal. pone.0168091

Gur, C., 2011, A guide for developing parenting styles, Trafford Publishers, New York.

Hensels, I.S., Sherr, L., Skeen, S., Macedo, A., Roberts, K.J. \& Tomlinson, M., 2016, 'Do not forget the boys-gender differences in children living in high HIV-affected communities in South Africa and Malawi in a longitudinal, community-based study', AIDS Care 28(suppl 2), 100-109. https://doi.org/10.1080/09540121.201 6.1176680

Holborn, L. \& Eddy, G., 2011, First steps to healing the South African family, A research paper by the South African Institute of Race Relations, Kagiso Trust, Johannesburg.

Holtzhausen, L., 2012, 'Thirteen year old boy implicated in gang rape of seventeen year old mentally disabled girl from Soweto: A case of criminal capacity', Article 40, 14(2), 1-5.

Icard, L.D., Jemmott, J.B., Teitelman, A., O'Leary, A. \& Heeren, G.A., 2014, 'Mediation effects of problem drinking and marijuana use on HIV sexual risk behaviors among childhood sexually abused South African heterosexual men', Child Abuse \& Neglect 38(2), 234-42. https://doi.org/10.1016/j.chiabu.2013.08.002

Jewkes, R. \& Morrell, R., 2017, 'Hegemonic masculinity, violence, and gender equality: Using latent class analysis to investigate the origins and correlates of differences between men', Men and Masculinities 21(4), 547-571.

Johnston, M. \& Krettenauer, T., 2011, 'Moral self and moral emotion expectancies as predictors of anti- and prosocial behaviour in adolescence: A case for mediation?', European Journal of Developmental Psychology 8, 228-243. https://doi.org/ 10.1080/17405621003619945

Keyes, C.L.M., 1998, 'Social well-being', Social Psychology Quarterly 61(2), 121-140. https://doi.org/10.2307/2787065

Keyes, C.L.M., 2002, 'The Mental health continuum: From languishing to flourishing in life', Journal of Health and Social Research 43, 207-222.

Keyes, C.L.M., 2009, 'The nature and importance of positive mental health in American adolescents', in R. Gilman, E.S. Huebner \& M.J. Furlong (eds.), Handbook of positive psychology in schools, pp. 9-23, Routledge, New York.

Kheswa, J.G., 2015, 'Psychological well-being, alcohol abuse and sexual behaviou of African adolescent males in South Africa', Journal of Psychology 6(1), 32-40. https://doi.org/10.1080/09764224.2015.1188552

Kheswa, J.G., 2017a, 'The impact of dysfunctional families and sexual abuse on the psychological well-being of adolescent females, Eastern Cape, South Africa', Journal of Sociology and Social Welfare XLIV(2), 161-176.

Kheswa, J.G., 2017b, 'The impact of unemployment on the sexual behaviour of male youth in Quzini, Eastern Cape, South Africa. A qualitative study', Oriental Anthropologists 17(1), 59-76.

Kheswa, J.G. \& Lobi, T., 2017, 'Factors enhancing the psychological well-being and positive sexual- behaviour of South African adolescent males', Anthropologist 30(1), 27-36. https://doi.org/10.1080/09720073.2017.1379141

Kocayörük, E., 2010, 'Pathways to emotional well-being and adjustment in adolescence: The role of parent attachment and competence', International Online Journal of Educational Sciences 2(3), 719-737.

Koen, V., 2009, The parent-adolescent relationship and the emotional well-being of adolescents, Unpublished Master's dissertation, North-West University, Vaal Triangle Campus, Vanderbijlpark.

Langa, M., 2016, 'The value of using a psychodynamic theory in researching Black masculinities of adolescent boys in Alexandra Township, South Africa', Men and Masculinities 19(3), 260-288. https://doi.org/10.1177/1097184X15586434

Lazarus, R.S. \& Folkman, S., 1990, 'Coping and emotion', in N.L. Stein, B. Leventhal \& T.R. Trabasso (eds.), Psychological and biological approaches to emotion, pp. 313-332, Lawrence Erlbaum Associates, Inc, Hillsdale, New Jersey.
Levine, S.Z., Laufer, A., Stein, E., Hamama-Raz, Y. \& Solomon, Z., 2009, 'Examining the relationship between resilience and posttraumatic growth', Journal of Traumatic Stress 22(4), 282. https://doi.org/10.1002/jts.20409

Liebenberg, L., Ungar, M. \& Van de Vijver, F., 2012, 'Validation of the child and youth resilience measure-28 (CYRM-28) among Canadian youth', Research on Social Work Practice 22(2), 219-226.

Louw, D. \& Louw, A., 2014, Child and adolescent development, University of FreeState, Bloemfontein.

Lyubomirsky, K., King, L. \& Diener, E., 2005, 'The benefits of frequent positive affect: Does happiness lead to success', Psychological Bulletin 131(6), 803-855.

Macnab, A., 2013, 'The Stellenbosch consensus statement on health promoting schools Global Health Promotion 20(1), 78-81. https://doi.org/10.1177/ 1757975912464252

Magidson, J.F., Dietrich, J., Otwombe, K.N., Sikkema, K.J., Katz, I.T. \& Gray, G.E. 2017, 'Psychosocial correlates of alcohol and other substance use among lowincome adolescents in peri-urban, Johannesburg, South Africa: A focus on
gender differences', Journal of Health Psychology 22(11), 1415-1425. https://doi. gender differences', Journal of Health
org/10.1177/1359105316628739

Makongoza, M. \& Nduna, M., 2017, 'Awareness and rejection accounts of intimate partner violence by young women in Soweto, Johannesburg, South Africa', Journal of Interpersonal Violence 32(1), 1-26. https://doi.org/10.1177/0886260517726413

Malebo, A., Van Eeden, C. \& Wissing, M.P., 2007, 'Sport participation, psychological well-being, and psychosocial development in a group of young black adults',
South African Journal of Psychology 37(1), 188-206. https://doi.org/10.1177/ South African Journal
008124630703700113

Masvawure, T.B., Sandfort, T.G., Reddy, V., Collier, K.L. \& Lane, T., 2015, 'They think that gays have money': Gender identity and transactional sex among Black men who have sex with men in four South African townships', Culture, Health \& Sexuality 17(7), 891-905. https://doi.org/10.1080/13691058.2015.1007168

Mcllwaine, C., 2012, 'Urbanization and gender-based violence: Exploring the paradoxes in the global South', Environment and Urbanization 25, 65-79. https:// doi.org/10.1177/0956247813477359

Melato, S.R., van Eeden, C., Rothmann, S. \& Bothma, E., 2017, 'Coping self-efficacy and psychosocial well-being of marginalised South African youth', Journal of Psychology in Africa 27(4), 338-344. https://doi.org/10.1080/14330237.2017.1 347755

Miller, J.A., Smith, E.A., Coffman, D., Mathews, C. \& Wegner, L., 2016, 'Forced sexual experiences and sexual situation efficacy South African youth', Journal of Research on Adolescence 26(4), 673-686. https://doi.org/10.1111/jora.12217

Morrissey, M.E., 2013, 'Rape as a weapon of hate: Discursive constructions and material consequences of black lesbianism in South Africa', Women's Studies in Communication 36(1), 72-91. https://doi.org/10.1080/07491409.2013.755450

Moshabela, M., Zuma, T., Orne-Gliemann, J., Iwuji, C., Larmarange, J., McGrath, N. \& ANRS 12249 TasP Study Group, 2016, "It is better to die": Experiences of traditional health practitioners within the HIV treatment as prevention tria communities in rural South Africa (ANRS 12249 TasP trial)', AIDS Care 28 (suppl 3), 24-32. https://doi.org/10.1080/09540121.2016.1181296

Müller, A., 2016, 'Health for all? Sexual orientation, gender identity, and the implementation of the right to access to health care in South Africa', Health and Human Rights 18(2), 195-208.

Müller, E.E., Rebe, K., Chirwa, T.F., Struthers, H., McIntyre, J. \& Lewis, D.A., 2016, 'The prevalence of human papillomavirus infections and associated risk factors in menwho-have-sex-with-men in Cape Town, South Africa', BMC Infectious Diseases 6(1), 440-453. https://doi.org/10.1186/s12879-016-1706-9

Mume, C.O., Olawale, K.O. \& Osundina, A.F., 2011, 'Excessive daytime sleepiness, nocturnal sleeps duration and psychopathology among Nigerian university
students', South African Journal of Psychiatry 17(4), 108-111. https://doi. students', South African Journal of
org/10.4102/sajpsychiatry.v17i4.311

Naidoo, L. \& Sewpaul, V., 2014, 'The life experiences of adolescent sexual offenders: Factors that contribute to offending behaviours', Social Work 50(1), 84-98. http://doi.org/10.15270/50-1-17

National School Climate Council, 2007, The school climate challenge: Narrowing the gap between school climate research and school climate policy, practice guidelines and teacher education policy, viewed 26 July 2015, from http://www. schoolclimate.org/climate/documents/policy/school-climate-challenge-web.pdf

Neff, K.D., 2011, 'Self-compassion, self-esteem, and well-being', Social and Personality Psychology Compass 5(1), 1-12. https://doi.org/10.1111/j.1751-9004.2010. 00330.x

Nkosi, S., Sikweyiya, Y., Kekwaletswe, C.T. \& Morojele, N.K., 2015, 'Male circumcision, alcohol use and unprotected sex among patrons of bars and taverns in rural areas of -north-west province, South Africa', AIDS Care 27(5), 612-617. https://doi.org /10.1080/09540121.2014.983040

Nolen-Hoeksema, S., 2008, 'It is not what you have; it is what you do with it: Support for Addis's gendered responding framework', Clinical Psychology: Science and Practice 15(3), 178 -181. https://doi.org/10.1111/j.1468-2850.2008.00128.x

Ntombana, L., 2011, 'An investigation into the role of Xhosa male initiation in moral regeneration', Doctoral thesis, Nelson Mandela Metropolitan University, Port Elizabeth.

Nyembezi, A., Ruiter, R.A., Van den Borne, B., Sifunda, S., Funani, I. \& Reddy, P., 2014 'Correlates of consistent condom use among recently initiated and traditionally circumcised men in the rural areas of the Eastern Cape Province, South Africa', BMC Public Health 14(1), 668. https://doi.org/10.1186/1471-2458-14-668

Ojala, M., 2013, 'Coping with climate change among adolescents: Implications for subjective well-being and environmental engagement', Sustainability 5(5), 2191-2209. https://doi.org/10.3390/su5052191 
Pastorino, E. \& Doyle-Portillo, S., 2011, What is psychology, Wadsworth Cengage Learning: Australia.

Peterson, Z.D., Janssen, E. \& Heiman, J.R., 2010, 'The association between sexual aggression and HIV risk behavior in heterosexual men', Journal of Interpersonal Violence 25(3), 538-556. https://doi.org/10.1177/0886260509334414

Pretorius, K., 2009, 'Support systems and coping strategies used by South in in African children of divorce', Doctoral dissertation, University of Stellenbosch, Stellenbosch.

Ratele, K., 2014, 'Currents against gender transformation of South African men: Relocating marginality to the centre of research and theory of masculinities', NORMA: International Journal for Masculinity Studies 9(1), 30-44. https://doi.org /10.1080/18902138.2014.892285

Ratele, K., Shefer, T. \& Clowes, L., 2012, 'Talking South African fathers: A critical examination of men's constructions and experiences of fatherhood and fatherlessness', South African Journal of Psychology 42(4), 553-563. https://doi. org/10.1177/008124631204200409

Rich, E.P., Nkosi, S. \& Morojele, N.K., 2015, 'Masculinities, alcohol consumption, and sexual risk behavior among male tavern attendees: A qualitative study in North West Province, South Africa', Psychology of Men \& Masculinity 16(4), 382. https:// doi.org/10.1037/a0038871

Roman, N.V., Makwakwa, T. \& Lacante, M., 2016, 'Perceptions of parenting styles in South Africa: The effects of gender and ethnicity: Social psychology, research in South Africa: The effects of gender
article', Cogent Psychology 3, 1153231.

Salovey, P. \& Mayer, J.D., 1990, 'Emotional intelligence', Imagination, Cognition and Personality 9, 185-211. https://doi.org/10.2190/DUGG-P24E-52WK-6CDG

Schultz, D.P. \& Schultz, S.E., 2009, Theories of personality, 9th edn., Wadsworth Cengage Learning, Australia.

Schultz, D.P. \& Schultz, S.E., 2013, Theories of Personality. International Edition Cengage Learning, New York.

Shai, N.J., Jewkes, R., Nduna, M. \& Dunkle, K., 2012, 'Masculinities and condom use patterns among young rural South Africa men: A cross-sectional baseline survey', BMC Public Health 12(1), 1. https://doi.org/10.1186/1471-2458-12-462

Skinner, E., Furrer, C., Marchand, G. \& Kindermann, T., 2008, 'Engagement and disaffection in the classroom: Part of a larger motivational dynamic', Journal of Educational Psychology 100, 765e781.

Suldo, S.M., McMahan, M.M., Chappel, A.M. \& Loker, T., 2012, 'Relationships between perceived school climate and adolescent mental health across genders', School Mental Health 4(2), 69-80. https://doi.org/10.1007/s12310-012-9073-1

Swartz, L., De la Rey, C., Duncan, N., Townsend, L. \& O’Neill, V., 2016, Psychology: An introduction, 4th edn., Oxford University Press Southern Africa, Cape Town.
Uma, L.S., 2011, 'Systematic reviews and meta-analyses', Journal of the Canadian Academy of Child and Adolescent Psychiatry 20(1), 57-59.

Ungar, M., 2011, 'The social ecology of resilience: Addressing contextual and cultural ambiguity of a nascent construct', American Journal of Orthopsychiatry 81(1), 1-17. https://doi.org/10.1111/j.1939-0025.2010.01067.x

Van Dyke, C.J., Glenwick, D.S., Cecero, J.J. \& Kim, S.K., 2009, 'The relationship of religious coping and spirituality to adjustment and psychological distress in urban early adolescents', Mental Health, Religion and Culture 12(4), 369-383. https:// doi.org/10.1080/13674670902737723

Walsh, J.L., Weinhardt, L.S., Kalichman, S.C. \& Carey, M.P., 2017, 'Using integrative data analysis to examine changes in alcohol use and changes in sexual risk behavior across four samples of STI clinic patients', Annals of Behavioral Medicine 51(1), 39-56. https://doi.org/10.1007/s12160-016-9826-4

Weiten, W., 2010, Psychology: Themes and variations, Wadsworth Cengage Learning, Hampshire.

Yendork, J.S. \& Somhlaba, N.Z., 2014, 'Stress, coping and quality of life: An exploratory study of the psychological well-being of Ghanaian orphans placed in orphanages', Children and Youth Services Review 46, 28-37. https://doi.org/10.1016/j. childyouth.2014.07.025

Zastrow, C. \& Kirst-Ashman, K., 2007, Understanding human behaviour and the socia environment, Thomson Brooks/Cole, Belmont, CA.

Zeman, J., Cassano, M. \& Adrian, M.C., 2012, '5 Socialization influences on children's and adolescents' emotional self-regulation processes', in K.C. Barrett, N.A. Fox, G.A Morgan, D.J. Fidler, \& L.A. Daunhauer (eds.), Handbook of self-regulatory processes in development: New directions and international perspectives, pp. 79-107, in development: New

Zembe, Y.Z., Townsend, L., Thorson, A., Silberschmidt, M. \& Ekstrom, A.M., 2015, 'Intimate partner violence, relationship power inequity and the role of sexual and social risk factors in the production of violence among young women who have multiple sexual partners in a peri-urban setting in South Africa', PLoS One 10(11), e0139430. https://doi.org/10.1371/journal.pone.0139430

Zhang, W., Chen, Q., McCubbin, H., McCubbin, L. \& Foley, S., 2011, 'Predictors of mental and physical health: Individual and neighborhood levels of education, social well-being, and ethnicity', Health \& Place 17(1), 238-247. https://doi. org/10.1016/j.healthplace.2010.10.008

Zuma, K., Shisana, O., Rehle, T.M., Simbayi, L.C., Jooste, S., Zungu, N. et al., 2016, 'New insights into HIV-epidemic in South Africa: Key findings from the National HIV prevalence, incidence and behaviour survey, 2012', African - Journal of AIDS Research 15(1), 67-75. https://doi.org/10.2989/16085906.2016.1153491 